\title{
A View to the Requirement of Designated Refuge Floors in High-rise Buildings in Hong Kong
}

\author{
SIU MING LO' \\ Department of Building \& Construction \\ City University of Hong Kong \\ Hong Kong \\ BARRY F. WILL2 \\ Department of Architecture \\ University of Hong Kong, Hong Kong
}

\begin{abstract}
In the recent decade, ultra high-rise buildings have been erected throughout Hong Kong. The safety of the occupants in these buildings under emergency situations are of prime importance. An evacuation system is not the first step of fire safety design in buildings, yet it cannot be eliminated as a hazard free environment cannot be provided. An effective evacuation system should be the major concern of the Government, the building designers as well as the people using the building. The Building Authority of the Hong Kong Government has issued fire codes to facilitate building design. However, of these codes, the Code of Practice on Means of Escape has not been fundamentally reviewed since its first publication in 1960. In 1991, the Government of Hong Kong established a working party to review the Code of Practice on Means of Escape in Hong Kong. In relation to the escape from ultra highrise buildings, the introduction of designated refuge floors has been proposed. This paper describes the background of the idea and provides a brief discussion in this aspect.
\end{abstract}

Keywords: Fire Codes, Psychological Reaction, Refuge Floor.

\section{INTRODUCTION}

Hong Kong is a densely populated city. The space available for erecting buildings is limited. In view of the growth of population, changes in family structure, and an increase in

Formerly Secretary, Working Party on the Review of the Codes of Practice on Means of Escape, Hong Kong; Member, Working Group on Fire Safety Engineering Approach, Buildings Department, Hong Kong Government and Assist. Prof., Department of Building and Construction, City University of Hong Kong.

Member, Working Party on the Review of the Codes of Practice on Means of Escape, Hong Kong and Dean, Faculty of Architecture, University of Hong Kong. 
business activities, the demand for built space has grown rapidly in the past two decades. Numerous high-rise/ ultra high-rise buildings ${ }^{3}$ have been erected. Office, commercial and private residential buildings erected in this period are commonly over 40 storeys and with about half the population of Hong Kong living in public housing estates and almost all the housing blocks constructed recently are over 35 storeys. This implies that a large number of people in Hong Kong live and work in high-rise/ ultra high-rise buildings. There is no doubt that the Government, the building designers as well as the people of Hong Kong are concerned for the safety of the occupants of these buildings especially under fire or emergency situations.

\section{THE BUILDING CONTROL IN HONG KONG}

The fire safety design of buildings in Hong Kong is mainly governed by the prescriptive codes of practices published by the Building Authority and the Fire Services Department. The major codes of practices are:-

a) the Means of Escape Code [1]

b) the Fire Resisting Construction Code [2]

c) the Means of Access For Fire Fighting and Rescue Code [3]

d) the Fire Service Installations Code [4]

Of all the fire codes, the Code of Practice on Means of Escape was the first published guidance which came into operation on 1st January, 1960. It provided guidance for the design of the sizes and capacities of various building elements. Although some minor amendments have been added to the code over the intervening years, the majority of the requirements have not been updated since its first publication. The rationale behind the requirements in the code was not given. It appeared that some of the standards were based on unknown judgments with respect to maximum egress distance, population and safe egress time rather than fully determined solutions based on research [5]. On the other hand, the fire service installations are usually separately considered by the Fire Services Department. The interrelationships of the passive and active means of fire safety design are not considered by the controlling authorities as a whole. In the circumstances, the Government in 1990 decided to update the requirements in the code and a working party on the review of the Code of Practice on Means of Escape was established. Subsequently, a draft code of practice on means of escape was completed in 1994 and distributed to the professional bodies in Hong Kong [the Hong Kong Institute of Architects (HKIA), the Hong Kong Institute of Engineers (HKIE), the Hong Kong Institute of Surveyors (HKIS), the Real Estate Development Association, etc.] for consultation. Subsequent to the extensive consultation, the new edition of the code of practice was published in June, 1996. The new code is still a prescriptive code and the majority of the requirements have not been altered. However, a few contentious requirements have been added. One of these issues is the provision of designated refuge floor(s) in high-rise/ ultra high-rise buildings. This paper aims at providing a view in this aspect taking into account the views of the regulators and the parties affected by the proposed change.

3 It is defined in this paper that high-rise buildings refer to those building of 15 stroey to 39 storeys and ultra highrise buildings refer to those buildings of 40 storeys or taller. 


\section{THE BASIC REASONS FOR USING REFUGE FLOORS}

In the Hong Kong new code, a refuge floor is considered as a part of the exit route in high-rise/ ultra high-rise buildings. It acts as a safe place for a short rest before people continue to escape downwards [6] as it is difficult for most people to walk down a tall building without pausing. It also acts as a safe passage for people using one staircase, when encountering smoke, fire or obstruction in that staircase and enables them to proceed to an alternative staircase. Additionally, it acts as a place of assembly for people to wait for rescue in case none of the staircases can be used due to smoke, fire or obstruction.

Obviously, the refuge floor is considered as a temporary safe place for the evacuees under fire situations. It is a place adopted temporarily to reduce the effective "travelling height" of the evacuees.

The major functions of a refuge floor can be summarised as follows [6]:

i) acts as a relief area for the evacuees under fire situations;

ii) acts as a subbase for firefighting purpose;

iii) acts as a command point by the rescue personnel to assist orderly evacuation of the building; and

iv) as a place allowing the disabled or partially disabled to wait for assistance before being evacuate to a place of ultimate safety.

The general principles of life safety from fire in high-rise/ ultra high-rise buildings is that there should be a minimum of two staircases for the occupants to leave in order to ensure that at least one exit route is available at all times. However, there may still be the chance that all the staircases are blocked off. For example, in summer, 1995, a fire occurred in a 10-storey residential/ commercial building in North Point, Hong Kong. All the staircases were blocked by smoke before all the occupants had left the building. Under these circumstances, about 30 to 40 evacuees escaped to the roof to await rescue [7]. In this case, the roof served as a refuge floor and eventually all the people were rescued. However, in some buildings, not all the staircases may lead to the roof and in many modern buildings the roof forms are either covered or pitched. In such buildings, if all the staircases were blocked by fire, the occupants lives would be at risk and refuge floors offer a safe alternative.

\section{THE CRITERIA IN ACHIEVING THE OBJECTIVES}

It has been found [8] that evacuees will normally experience fatigue while travelling in a downwards direction after approaching nearly about 5 minutes [i.e. about 300 seconds]. The average speed of the evacuees' travel down one storey with a normal headroom of $2.8 \mathrm{~m}$ per floor in Hong Kong is about 16 seconds [9]. In this connection, the fatigue will be in when the evacuees have travelled about 18 storeys. Based on this aspect, if the refuge floor is adopted as a "rest place", then the logical location of refuge floors is at 18 storey intervals. By allowing 
some deviation in storey height for different buildings and for different rate of movement of people, the new code [1] has stated that refuge floors should be provided in all buildings exceeding 25 storeys at intervals of not less than 20 storeys and not more than 25 storeys.

To perform these functions well, a refuge floor should be a safe and comfortable place to stay. It should have sufficient area to accommodate most of the occupants who are expected to temporarily halt at the floor. It should have adequate height, lighting, ventilation as well as guidance signage. As the refuge floor is considered a temporary safe place, it should have sufficient fire resisting properties and adequate ventilation to prevent the retention of smoke. The new code has stated that the refuge floor should be separated from the remainder of the building with appropriate fire resisting construction (the Fire Resisting Period for the separating elements is required to be 2 hours with respect to stability, integrity and insulation) and the area for refuge should be open-sided on at least two sides to provide adequate cross ventilation $[1,2]$.

The design and layout of exit staircases requires evacuees to discharge into the refuge floor before being permitted to proceed downwards. By this method, the control of the evacuation process may be instituted at every refuge floor. The process can be illustrated by Figure 1 .

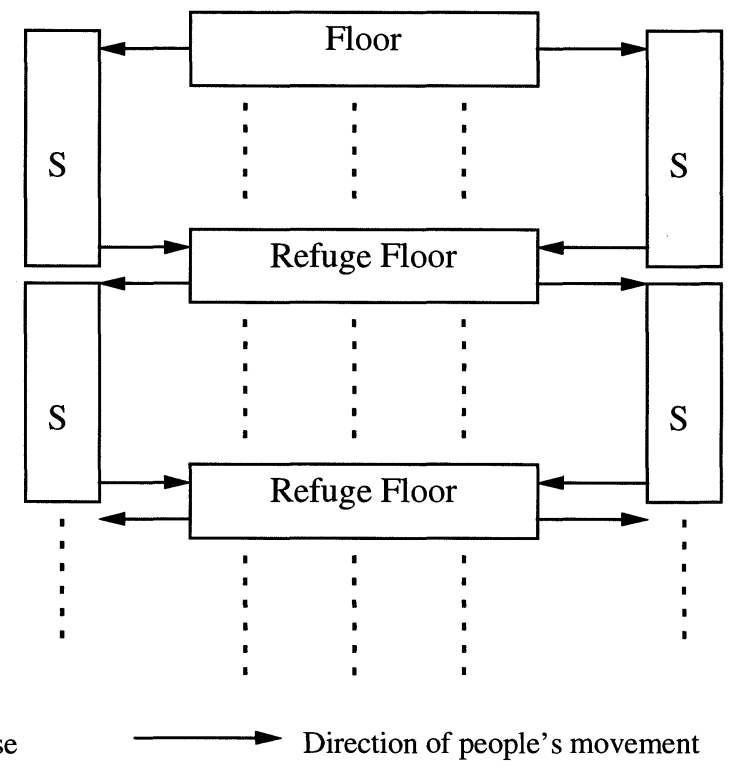

FIGURE 1: Direction of movement of people

As water which may accumulate on a refuge floor will affect the safety use of the area for refuge, a refuge floor should be suitably waterproof and drained. 
The refuge floor mentioned above is considered as part of the exit system. It serves as an interim rest place for the people under evacuation and therefore, it is important to ensure that the area is free from obstructions with well maintained signage and lighting. Good management therefore plays an essential role in maintaining the function of a refuge floor.

Adequate stimulating features, such as signage, should be provided at appropriate locations to assist in the wayfinding process. At the point of discharge and re-entry into exits, interactive emergency signs and voice communication methods may be used to direct evacuees.

\section{THE PSYCHOLOGICAL REACTION OF PEOPLE TO THE PRESENCE OF A REFUGE FLOOR}

The use of a refuge floor can psychologically assist the occupants under escape conditions as this action involves a spatial problem solving process [12]. Cognitive mapping plays a central role in the people's ability to solve spatial problems [13]. The refuge floor which has been stored as an image within the users' cognitive map can influence the movement of the individual. This cognitive map will be built up by rehearsed fire drills which are considered essential in any properly managed high-rise building. This familiarity will encourage the users to approach the focal point - the refuge floor and organize their way to leave the building in a rational and controlled manner.

Under emergency situations, the occupants will experience environmental stress. There are three types of personal control, namely behavioural control, cognitive control and decisional control, that people can exert over threatening circumstances [14]. The behavioural control refers to actions that can directly modify the threatening event such as extinguishing the fire. Cognitive control refers to the way an individual interprets the threatening event. The presence of refuge floors can reassure users that the height of their escape is not extensive. The refuge floor serves as an image of safe place. The decisional control is defined in terms of the range of choices available to an individual. During evacuation from the highest floors of a high-rise/ ultra high-rise building, the refuge floor can serve as an intermediate point where the evacuees can have the choice of taking a rest, waiting for rescue or continuing the escape. Obviously, the refuge floor can psychologically assist the evacuees in reducing their stress during evacuation by offering cognitive and decisional control.

The refuge floor can serve as a basis for the firemen to fight the fire. Once people have reached a refuge floor and see fire fighters there, they will be psychologically relieved and more confident of their personal safety. It may be due to the fact that a firefighter is in general a sign of safety in an evacuee's cognitive map. The primary concept of refuge floors is to provide a place for a break and to release the people's stress when they proceed down to the ultimate place of safety.

Moreover, at the refuge floor, passenger lifts not serving the fire floor can, with the assistance of fire fighters, also be used for people evacuating from the refuge floors. One of the arguments of not using lift for evacuation is that it is difficult to control the crowd movement if most of the people are under stress. Psychologically, the stress of the people at the refuge 
floor may be reduced. It may be feasible for the rescue personnel to control the evacuation process by using lifts. This is particularly important where the elderly, children or handicapped users are involved in the evacuation process.

In order to "reinforce" the image of refuge floors in the cognitive maps of the evacuees, the users of the building should be informed that the existence of refuge floors in the building. A plan showing the relative locations of refuge floors should be placed in a conspicuous part of the building such as at the main lift lobby. In addition, the general public should be educated that refuge floors are provided in high-rise/ ultra high-rise buildings and they are used as temporary safe places. If such ideas have been formulated in people's minds, the stress level of those people situated at an extremely high levels may be reduced. Staff training, the establishment of contingency planning and fire drills can be adopted to reinforce the refuge floor image.

\section{THE ARGUMENTS}

The use of refuge floors in high-rise/ ultra high-rise buildings as introduced by the new code was opposed by the professional bodies [HKIA, HKIE, HKIS, etc.] in Hong Kong. They had the following major comments [10]:

i) The protected routes of an exit system are in the form of corridors and staircases. These components are adequate to allow the evacuees to leave the building and an interim safe place is not necessary. Extended travel in the exit systems is not particularly arduous.

ii) The fatigue which happens for some evacuees under extended travel in staircases may not create too much of a problem unless the density inside the staircase is so high that obstruction occurs.

iii) It is doubtful whether the evacuees will stay in the refuge floor awaiting rescue. The refuge floor may be useful for those who find difficulty in escape.

Travel in the protected routes may not be arduous if the building is not substantially high. In buildings over 40 storeys, which are commonly found in Hong Kong, evacuees' travel time by moving continuously from the topmost floor to the ground level may require 10 to 12 minutes. Intermediate rest appears necessary for most people. If the staircase is crowded, such an obstruction may create a hazard to the evacuees as well as increasing the evacuation time of the people inside the building. In Hong Kong, most commercial buildings are densely populated and with these high populations, it is particularly necessary to designate a place for refuge.

In residential buildings, the population density is not as high. But, the pre-evacuation time may be very long, especially when most of the occupants are asleep. The possibility that all the staircases are blocked by smoke or fire in the pre-evacuation period may be higher. Refuge floors may then be necessary to serve as a temporary safe places in the escape process. 
The refuge floor is not primarily designed as a place for the evacuees to remain and await for rescue but it may have to perform this role if all the escape routes below are blocked. Normally, it should be regarded as a buffer zone to assist the movement of the people in highrise/ ultra high-rise buildings. A dependency on emergency management for effective evacuation of occupants from high-rise/ ultra high-rise buildings is always a problem. Thus, a concept where such dependency may be reduced should merit serious consideration [11]. Refuge floors which serve as zones to reduce the effective height of a building can help to engender phased evacuation and to simplify these processes.

If the fire doors of the staircase core are opened, smoke is able to migrate to the staircase. The refuge floor can be adopted to segregate the staircases into segments in order to prevent total smoke logging throughout the entire staircase.

Apart from the arguments put forward by the professional bodies, the introduction of refuge floors can cause other problems. Maintaining the effectiveness of refuge floors may not be a simple matter. The population growth in Hong Kong and the influx of immigrants has inevitably led to a huge demand for floor space. Under these circumstances, unauthorized building works and unauthorized changes of use in buildings which can provide readily available floor space have always been a problem in Hong Kong [15]. Refuge floors are a readily available spaces which could be misused. From a management point of view, a refuge area which is an extended portion of the exit route will be easier to manage than a complete floor dedicated to refuge purposes. However, from a psychological point of view, the image of an extended portion of exit route may not be as effective as a complete refuge floor. The benefits of using refuge floors to release the psychological stress of the evacuees may be of a higher priority.

The new code recognizes the importance of effective maintenance in the introduction of refuge floors. In the commentary accompanying the code [6], the building management in relation to the use of refuge floors has been spelt out. In order to maintain a clear and unobstructed refuge floor, effective statutory control should be considered. In Hong Kong, the relevant authorities have the duty to carry out regular inspections of the refuge floors which is regarded as part of the exit route. If an obstruction is noted, a "fire hazard abatement notice" (under the Fire Services Ordinance) or an "illegal structure removal notice" (under the Buildings Ordinance) may be served to cause the obstructions to be removed. However, such approaches can only be regarded as passive means of control. A more positive approach could be the adoption of a certification system to ensure the efficiency of the refuge floors. The owners of the building would be required to produce a certificate issued by recognized persons or bodies annually (or within a reasonable period of time) to demonstrate the efficiency of the refuge floors.

Apart from the managerial problems, the use of refuge floors may increase the cost of construction especially where a complete floor for refuge purposes is incorporated into crosswall construction as is commonly found in high-rise residential blocks in Hong Kong. The new code takes account of this in its provision for permitting part of the refuge floor to be used for building services (with adequate fire separation) and this permits staged pumping, for example, and other utilities at intermediate levels of the building. In Hong Kong, the construction cost of a building is normally a small portion of the development cost. The land values, in some 
cases, may responsible for up to $90 \%$ of the development cost. Therefore, the provision of refuge floors in large development projects may merely cause a small percentage increase in the total cost. It implies that the provision of refuge floor is cost viable in Hong Kong's situation.

The effectiveness of refuge floors under fire situations may be impaired if the floor is affected by smoke from lower levels. The current requirements for cross ventilation may not guarantee that smoke logging will not occur particularly under adverse weather conditions. Further studies with respect to this area are necessary.

\section{CONCLUDING REMARKS}

The refuge floor concept may facilitate the evacuation process in ultra high-rise buildings. Its image can help to release the stress of the evacuees. It serves as a buffer zone and simplify the evacuation process whilst acting as a basepoint for the firefighters and rescue personnel to initiate escape by using lifts.

The provision of refuge floors is a prescriptive requirement in the Code of Practice. Such a provision appears to be desirable by the regulators as it relates to simple rules and has administrative convenience. Nevertheless, the purpose of the rules need to be understood by the designers so that alternative approaches to fire safety design in buildings as embodied by the newly published fire codes $[1,2,3]$ can be made. In addition, a long term monitoring of the effects of designated refuge floors in all aspects including technical, social and economic aspects should be carried out.

\section{REFERENCES}

1. Code of Practice for Means of Escape, Hong Kong, Hong Kong Government, 1996.

2. Code of Practice for Fire Resisting Construction, Hong Kong Government, 1996.

3. Code of Practice for Means of Access for Fire Fighting and Rescue Purposes, Hong Kong Government, 1995.

4. Code of Practice for Minimum Fire Service Installations and Equipment, Hong Kong Government, 1994.

5. Lo, S.M., (1995), "Fire Safety Design in Buildings of Hong Kong: A Preliminary View", Asia Pacific Building and Construction Management Journal, vol. 1, pp.41-50, ISSN 1024-9540.

6. Commentary, Code of Practice on Means of Escape, Hong Kong, Hong Kong Government, 1996.

7. Ming Pao Daily News, 14 May, 1995, p.B5.

8. Egan, M.D. , (1986), "Concepts in building fire safety", Robert Krieger Publishing Co..

9. Pauls, J., (1987) "Calculating evacuation times for tall buildings", Fire Safety Journal, 12, pp.213-236.

10. Review and comment on the draft code of practice on means of escape, submitted by HKIA, HKIE, HKIS, HKCA, and REDA, to the Building Authority, August, 1994, (unpublished). 
11. Teh, Ken-jin, (1994), "Concepts in the design for fire safety in tall buildings", Fire Engineers Journal, Pacific Rim Ed., vol. 54 No. 172.

12. Lo, S.M. and Will, B.F., (1995), "An approximate analysis method of perceptual reaction for emergency evacuation", Proceedings, Asiaflam'95 - An International Conference on Fire Science and Engineering, pp.151-162.

13. Passini, R., (1984), "Wayfinding in Architecture", Environmental Design Series, Van Nostrand Reinhold Co..

14. Averill, J., (1973), "Personal control over aversive stimuli and its relationship to stress", Psychological Bulletin, vol.80, pp.286-303.

15. Building Control in Hong Kong, Buildings and Lands Department, Hong Kong Government, 1991. 
